\title{
ADDITIONAL VALID RECORD OF MARBLED HAWKFISH, Cirrhites pinnulatus (BLOCH \& SCHNEIDER, 1801) (PERCIFORMES: CIRRHITIDAE) FROM NORTH SULAWESI
}

\author{
Teguh Peristiwady ${ }^{1}$ \\ 1) Technical Implementation Unit for Marine Biota Conservation, Indonesian Institute of Sciences, Bitung \\ Received September 16-2008; Received in revised form October 28-2008; Accepted November 7-2008
}

\begin{abstract}
The specimen of marbled hawkfish, Cirrhites pinnulatus (Bloch \& Schneider, 1801) (136.30 mm $\mathrm{SL}$ ) was collected by spear gun from reef flat of Kema, Bitung, North Sulawesi. Some valid record of this species were found and recorded from Indo-Pacific and Indian Ocean. From Indonesian waters were recorded this species from Pariaman, Bali, and Talaud. The recent Indonesian records were mostly recorded by census visual study such from Rajaampat Islands, Bali Island, Komodo, and Manado. Its morphological features and diagnostic characters are discussed and illustrated.
\end{abstract}

\section{KEYWORDS: Cirrhites pinnulatus, Perciformes, Cirrhitidae, coral reefs}

\section{INTRODUCTION}

The Indo-Malay Archipelago has long been considered the area of highest marine biodiversity (Bellwood \& Wainwright, 2002; Mora et al., 2003). With the other waters regions, the north Sulawesi waters were situated in the Western Central Pacific. It characterized with various ecosystems such as mudflats, coral reefs, estuaries, mangrove swamps, coastal areas, and continental shelves. Marine fishes is one of the main marine food resources in this area and is also constitute an important export product especially tuna. The fishing activity is dominated by tuna and other small pelagic fisheries by using pool and line or long line boats. Small pelagic and coral reef fishes were dominant at the local market and the most widely used gear is traditional net, such as light fishing, bamboo trap, seine net, and gill net.

Studies on fish in Indonesia are still insufficient. Scientific fish collections in Indonesia began with the visits of European explorers in the early $19^{\text {th }}$ century, following by Dutch researchers. Historically, the Indonesian fish specimen mostly were deposit at the United States National Museum of Natural History in Washington, D. C. and the Bishop Museum in Honolulu. Other museums are the Academy of Natural Sciences, Philadelphia; Museum National d'Histoire Naturelle, Paris; Nationaal Natuurhistorisch Museum, Leiden; The Natural History Museum, London; Universiteit van Amsterdam, Amsterdam; Western Australian Museum, Perth and Museum Zoologicum Bogoriense, Bogor, Indonesia (Allen \& Adrim, 2003). The fish specimen collection at Recearch Center for Oceanography (formerly labeled by NCIP), Jakarta is now transferred to Museum Zoologicum Bogoriense, Bogor, Indonesia.
Amongst the coral reef fish, family Cirrhitidae is one of the important fish under order Perciformes. This fish family belongs to the sub order Percoidei. Hawkfish are small to medium-sized marine fishes and are strictly tropical, associated with the coral reefs. Randall (1963) has revised the family Cirrhitidae. Nelson (1984) divided this family into 9 genera with about 32 species. Randall, 2001 in Carpenter \& Niem, 2001 mentioned the hawkfish consists of 10 genera and 38 species, 33 of which occur in the Indo-Pacific region; 19 species are found in the Western Central Pacific.

In the West Central Pacific region family Cirrithidae represent by 9 genera (Amblycirrhitus, Cirrhitichthys, Cirrhitops, Cirrhitus, Cyprinocirrhites, Isocirrhitus, Neocirrhites, Oxycirrhites and Paracirrhites) and 45 species (Randall, 2001 in Carpenter \& Niem, 2001). Genera Cirrithus in the area was represenred by Cirrhitus albopunctatus Schultz, 1950 and Cirrhitus pinnulatus (Foster in Bloch \& Schneider, 1801) (Randall, 2001 in Carpenter \& Niem, 2001).

The purpose of the present study is to inventory a new finding on fish species from the Indonesian waters. Thus, it is hope that this new finding will be used as a new baseline of the fisheries sciences which can stimulate future research in North Sulawesi and eastern Indonesian in general.

\section{MATERIALS AND METHODS}

The specimen of Cirrhites pinnulatus (Bloch \& Schneider, 1801), LBRCF-332, $136.30 \mathrm{~mm}$ SL was collected by spear gun at a depth of 3 to $5 \mathrm{~m}$ at the reef flat of Kema, Bitung, North Sulawesi on March $1^{\text {th }} 2008$. After collection, the specimens were 
immediately photographed, labeled with LBRCF (Reference Collection of Indonesian Institute of Sciences Bitung-Fish) and preserved in formalin solution $10 \%$ and deposit at Technical Implementation Unit for Marine Biota Conservation, Indonesian Institute of Sciences, Bitung for further study. Valid record of the fish specimen was used data from Fishbase (Froese \& Pauly (ed.), 2006 and Eschmeyer (ed.), 1998).

Cyanin blue was used to examine and count scales. Counts and measurements of meristic and morphological character were made on the left side of specimen by using dial point caliper to the nearest of $0.05 \mathrm{~mm}$. Length is recorded to $0.05 \mathrm{~mm}$ only for sizes under $150 \mathrm{~mm}$, length bigger than $150 \mathrm{~mm}$ is recorded to tenths of $\mathrm{mm}$. Total length is measured from the tip of snout to the tip of caudal fin. Standard length is taken from the front of the upper lip to the base of the caudal fin (end of hypural plate). Head length is measured from the front of the upper lip in the median plane to the end of the opercular membrane. Snout length is taken from the same anterior point to the fleshy edge of the orbit. Body depth is the greatest depth from the base of the dorsal fin, adjusting for any obvious malformations of preservation. Body width is the maximum width just behind the gill opening (anterior to the base of the pectoral fins). Orbit diameter is the greatest diameter to the fleshy edges of the orbit. Interorbital width is measured between eyes on top of head area. The length of the upper jaw is measured from the front of the upper lip to the posterior fleshy edge of the jaw. The depth of the caudal peduncle is the least depth, and the length of the caudal peduncle is taken horizontally from the rear base of the anal fin to the base of the caudal fin. Lengths of the dorsal and anal spines and rays are measured from the point they depart from the contour of the body. Dorsal fin base is taken from the anterior base of first dorsal rays to the end of the dorsal fin rays. Pectoral and pelvic fin lengths are the lengths of the longest ray. Anal fin base is taken from the base of anterior anal fin rays to the base of the end of anal fin rays.

\section{RESULTS AND DISCUSSION}

Family Cirrhithidae (Randall, 2001 in Carpenter \& Niem, 2001)

Oblong fishes (size to about $30 \mathrm{~cm}$ ), body depth 2 to 4.6 times in standard length. A fringe of cirri on posterior edge of anterior nostril. Two indistinct spines on opercle. A row of canine teeth in jaws, the longest usually anteriorly in upper jaw and half way back on lower jaw; a band of villiform teeth inside the canines, broader anteriorly (in lower jaw only anteriorly). One or more cirri projecting from tips of interspinous membranes of dorsal fin. Dorsal fin continuous, with $X$ spines and 11 to 17 soft rays, cirri on interspinous membrane, notched between spincus and soft portions; anal fin with III spines and 5 to 7 (usually 6) soft rays; pectoral fins with 14 rays, the lower 5 to 7 rays unbranched and usually enlarged, with the membranes deeply incised; pelvic fins with I spine and 5 soft rays. Principal caudal fin rays 15 . Branchiostegal rays 6 . Scales cycloid or ctenoid. Swimbladder absent. Vertebrae 26 to 28. Colour variable with species.

\section{Genus Cirrhitus Lacepède, 1803}

Elongate, rather compressed. Snout obtuse, the mouth far below level of eye. Body covered with moderate scales. Head scaly, excepting snout. Scales on cheeks and on inter and subopercle small, those of opercle large, but the anterior ones small. Strong canines in the upper and lower jaw, besides villiform teeth. Teeth on vomer and generally also on palatines. Dorsal with $X$ spines and 11 (12) soft rays. Anal with III spines and $6(7)$ rays. Pectoral with 7 simple rays. Caudal truncate or slightly rounded.

\section{Cirrhites pinnulatus (Bloch \& Schneider, 1801) (Figure 1)}

In the natural conditions, Coral Hawkfish (Cirrhitichthys falco), ring eye hawkfish (Paracirrhites arcatus) and freckled hawkfish (P. forsteri) are the most popular amongs the hawkfish. Out of these three species, the Marbled hawkfish is one of the un commonly seen.

Observations and measurements based on a single specimen, LBRCF-332, $136.30 \mathrm{~mm} \mathrm{SL}$, March $1^{\text {th }} 2008$, Market Collection, catch by spear gun, Kema, Bitung, North Sulawesi.

\section{Diagnostic Characters}

Counts and measurements of specimen were presented at Table 1. Dorsal fin continuous with $X$ spines and 11 soft rays, deeply notched between spinous and soft portions; each dorsal fin spine with a cirri from membrane near tip; anal fin with III spines and 6 soft rays; caudal fin truncate; pectoral fins not reaching a vertical at tips of pelvic fins; pectoral fin rays 14 , the lower 7 un branched and thickened. Lateral line scales 39; scales on cheek much smaller than scales on body. 
Body depth 2.68 times in standard length. Rounded head with big lips. Snout short and blunt. Mouth large and oblique, the maxilla nearly reaching a vertical at posterior edge of eye; upper margin of preopercle finely serrate. Supraorbital ridge low. Nostrils rounded, the anterior one with a posterior flap. Teeth in the jaws pointed forming a row, the anterior teeth in the lower jaw more strong canines; in the upper jaw only the anterior teeths are canines. A few rows of small teeth on the vomer and a single row of similar teeth on the palatines. Dorsal spines strong; their membranes deeply incised. Forth and fifth spines almost equal, longer than the others. Last spine about half length of first dorsal ray, which is equal to snout and eye together. First and third anal spine almost equal; first anal ray less than head length. Lower unbranched pectoral rays longer than the upper. Pelvic fin rounded. Caudal truncate, slightly rounded when expanded.

Figure 1. Marbled hawkfish, Cirrhites pinnulatus (Bloch \& Schneider, 1801); LBRCF-332, 136.30 mm SL.

\section{Color}

Color of fresh specimen: Fresh specimen reddish brown mottling on body, ground colour white but overlaid with dark reddish brown blotches and numerous dark orangish to reddish brown spots; ventral thorax and abdomen white; head with reddish brown spots, sometimes conjoined to form irregular bands; median fins with reddish brown spots. Pelvic fins whitish. Pectoral fins reddish. Size Maximum total length $30 \mathrm{~cm}$, commonly about $20 \mathrm{~cm}$.

Colour of preserved specimen: Preserved specimen reddish or violet grey. Head and body with numerous reddish-brown spots, forming more or less distinct longitudinal stripes on sides of head. Large white blotches on side. Belly whitish. Chin with a dark brown blotches forming a wide band, fins with exception of the pelvic, spotted with brown.

\section{Habitat and Biology}

Found on rocky shallow areas standing up by their pectoral fins. Family Cirrithidae don not have a swimbladder and are therefore are not a good swimmers. Field observation showed that fish always "take a rest" on the bottom by using their free pectoral spines or to cling among ra:.ififications of corals. Fishes belonging to the Oxycirrhites kinds and Cyprinocirrhites live at deeper water. Several species live on reefs or each individual choose a good point that permits him to observed the vicinities. Feeds mainly on crabs and generally caught from coral reef area, usually by hook and line or spear.

\section{Distribution}

Occurs through out the Indo-Pacific region from the Red Sea south to Port Alfred (South Africa) and east to French Polynesia and the Pitcairn Group; in the western Pacific from southern Japan to the Great Barrier Reef (Figure 2).

Some valid record of this species were found and recorded from Christmas Island, Indian Ocean (Allen \& Steene, 1988), the Cocos (Keeling) Islands (Allen \& Smith-Vaniz, 1994), Lutao Island, Taiwan (Chang et al., 1983), Lord Howe, Norfolk, \& Kermadec Islands, 
Southwest Pacific Ocean (Francis, 1993), Papua New Guinea (Kailola, 1987), Caribbean and the Red Sea (Lieske \& Myers, 1994), Japan (Masuda et al., 1984), Hawaiian Archipelago (Mundy, 2005), Micronesian (Myers, 1991), Vietnam (Phung et al., 1995), Maldives Islands (Randall \& Anderson, 1993), the South China
Sea (Randall \& Lim, 2000), Oman (Randall, 1995), the Great Barrier Reef and Coral Sea (Randall et al., 1990), the Ogasawara Islands (Randall et al., 1997), the Chagos Archipelago (Winterbottom \& Anderson, 1997) as Figure 3 (Froese \& Pauly (ed.), 2006).

Table 1.

Counts and measurements of Cirrhites pinnulatus (Bloch \& Schneider, 1801)

\begin{tabular}{|c|c|c|}
\hline \multicolumn{2}{|c|}{ Counts and measurements (mm) } & LBRCF-332 \\
\hline \multirow[t]{6}{*}{ Counts } & Dorsal fin rays & $\mathrm{X}, 11$ \\
\hline & Anal fin rays & III, 6 \\
\hline & Pectoral fin rays & Uppers rays 6 , lower rays 7 tickened and unbranched \\
\hline & Ventral fin rays & I, 5 \\
\hline & Caudal fin rays & 11 \\
\hline & Lateral line scales & 39 \\
\hline \multirow[t]{36}{*}{ Measurements } & Body and head & Length $(\mathrm{mm})$ \\
\hline & Total length & 167.00 \\
\hline & Standard Length & 136.30 \\
\hline & Body depth & 50.85 \\
\hline & Body width & 30.75 \\
\hline & Head length & 54.20 \\
\hline & Snout length & 18.05 \\
\hline & Orbit diameter & 11.05 \\
\hline & Interorbital width & 10.65 \\
\hline & Upper jaw length & 23.95 \\
\hline & Predorsal length & 51.70 \\
\hline & Preanal length & 95.80 \\
\hline & Prepelvic length & 56.60 \\
\hline & Caudal peduncle depth & 11.75 \\
\hline & Caudal peduncle length & 29.90 \\
\hline & Dorsal fin & \\
\hline & Dorsal fin base & 79.10 \\
\hline & First dorsal spine & 6.50 \\
\hline & Second dorsal spine & 12.25 \\
\hline & Thirth dorsal spine & 16.05 \\
\hline & Fourth dorsal spine & 18.50 \\
\hline & Fifth dorsal spine & 17.90 \\
\hline & Longest dorsal ray & 22.95 \\
\hline & Anal fin & \\
\hline & Anal fin base & 18.50 \\
\hline & First anal spine & 15.70 \\
\hline & Second dorsal spine & 23.60 \\
\hline & Thirth dorsal spine & 16.90 \\
\hline & Longest anal ray & 28.05 \\
\hline & Caudal fin & \\
\hline & Caudal-fin length & 24.95 \\
\hline & Pectoral fin & \\
\hline & Pectoral fin length & 27.70 \\
\hline & Pelvic fin & \\
\hline & Pelvic spine length & 20.00 \\
\hline & Pelvic fin length & 25.05 \\
\hline
\end{tabular}




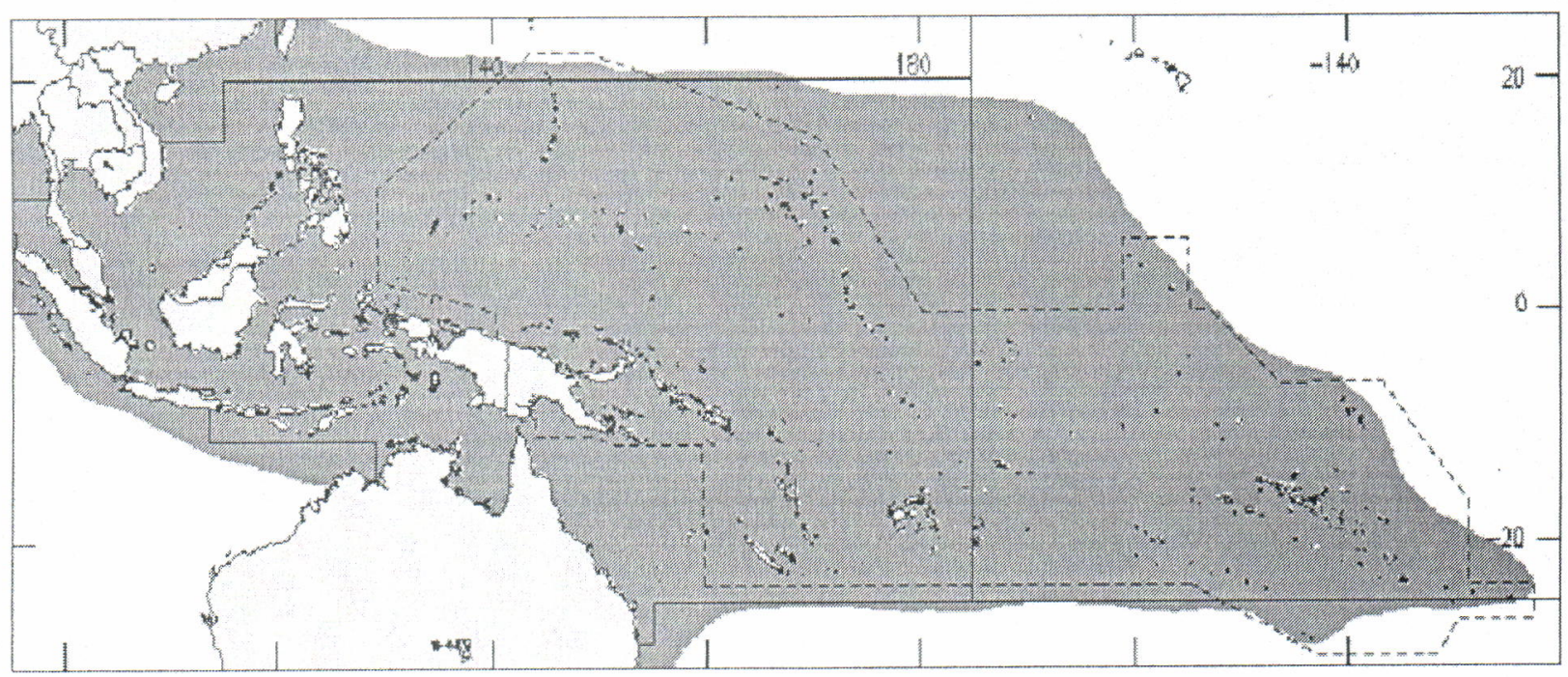

Figure 2

Geographic distribution of Cirrhites pinnulatus (Bloch \& Schneider, 1801) at western Central Pacific (Randall, 2001 in Carpenter \& Niem, 2001).

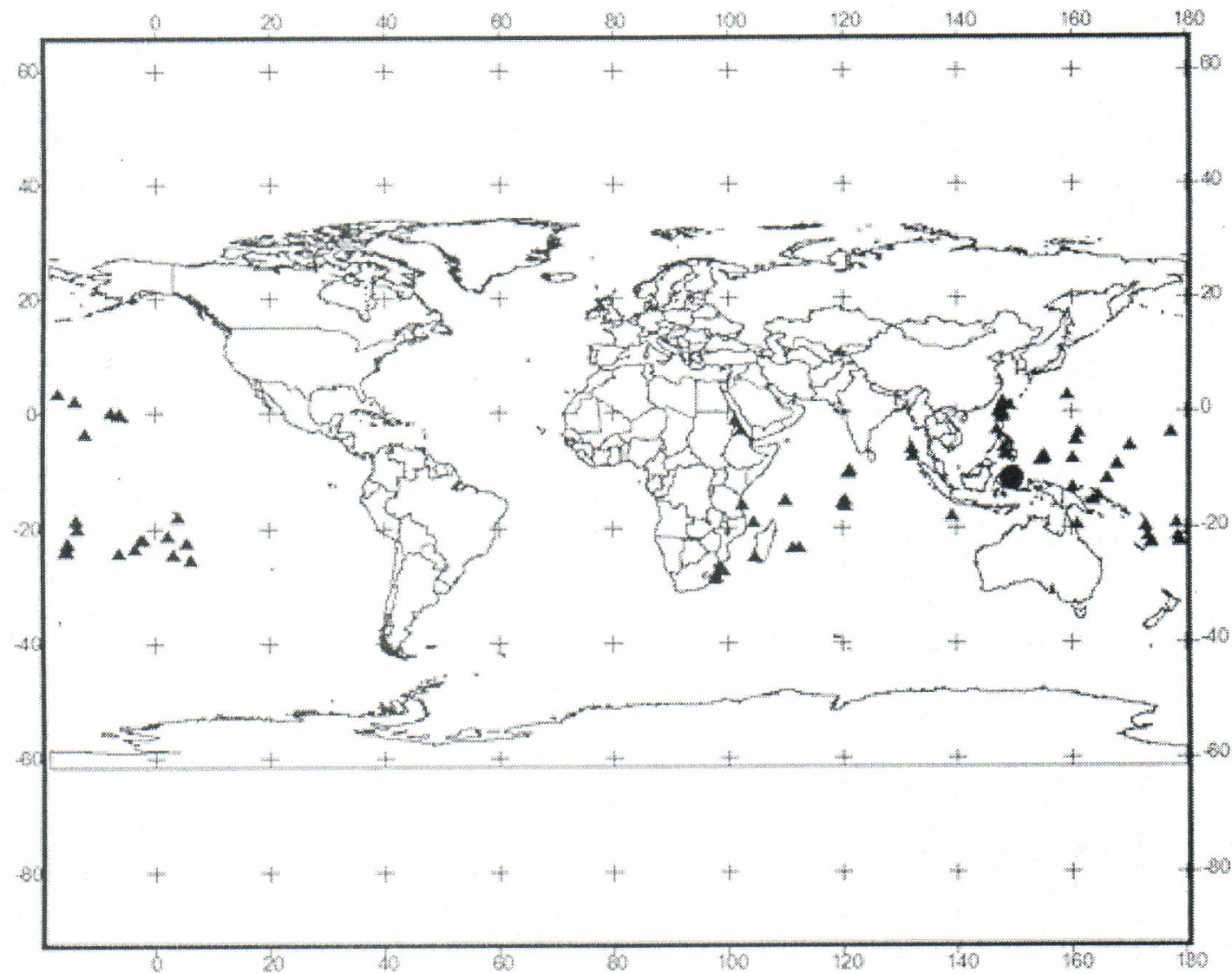

Figure 3. Geographic distribution of Cirrhitus pinnulatus (Bloch \& Schneider, 1801) at western Central Pacific were represented by triangle (position were downloaded from Froese \& Pauly (eds.), 2006) and specimen collected from Indonesia was represented by circle. 
From Indonesian waters, De Beaufort (1940) recorded this species from Pariaman, Bali, and Talaud. But mostly Indonesian record were found by sensus visual study such from Rajaampat Islands, Bali Island, Komodo, and Manado (Allen \& Adrim, 2003; Kuiter \& Tonozuka, 2001). Allen \& Adrim (2003) noted that Indonesian specimen were deposit at Western Australian Museum but without any detail location.

Most hawkfish are solitary but some will form pairs and share a head of coral or coral rubbel. They are diurnal and remain within the shallows of the reef, inhabits reef fronts and rocky shorelines exposed to depths of about $3 \mathrm{~m}$. Typically motionless and laid down on the high position of the reef to observe surroundings. Feeds primarily on crabs, crustaceans, small fishes, sea urchins or brittle stars. In natural condition, the hawk fish seek the high position of the reef where they can survey their surroundings. Most hawk fish are solitary but some will form pairs and share a head of coral. They are diurnal and live at the depths of less than 30 metres.

\section{ACKNOWLEDGEMENT}

I am very grateful to the reviewers for all suggestions and corrections. I also express my sincere gratitude to Dr. S. Kimura, Fisheries Research Laboratory of Mie University, Mie, Japan for the visit of first author in his laboratory and checked the specimen. And also to JSPS by Dr. K. Matsuura, Collection Director at National Museum of Nature and Science, Tokyo-Japan to support first author visiting Japan.

\section{REFERENCES}

Allen, G. R. \& Adrim, M. 2003. Coral reef fishes of Indonesia. Zoology Study. 42 (1). 1-72.

Allen, G. R. \& R. C. Steene. 1988. Fishes of Christmas Island Indian Ocean. Christmas Island Natural History Association, Christmas Island, Indian Ocean, Australia. 197 pp.

Allen, G. R. \& Smith-Vaniz, W. F. 1994. Fishes of the Cocos (Keeling) Islands. Atoll Research Bulletin. 412. 21. p. 13.

Bellwood, D. R. \& P. C. Wainwright. 2002. The history and biogeography of fishes on coral reefs. In P. F. Sale (ed.). Coral Reef Fishes. Academic Press. New York. pp. 5-32.
Chang, K. H., R. Q. Jan, \& K. T. Shao. 1983. Community ecology of the marine fishes on Lutao Island, Taiwan. Bulletin Inst. Zoology Academia Sinica 22 (2). 141-155.

De Beaufort, L. F. 1940. The fishes of the IndoAustralian archipelago. Vol.VIII. Percomorphi (continued). Cirrhitoidea, Labriformes, Pomacentriformes. J. Brill Ltd. Leiden. 508 pp.

Eschmeyer, W. N. (ed.). 1998. Catalog of fishes electronic version. San Francisco: California Academy of Sciences.

Francis, M. P. 1993. Checklist of the coastal fishes of Lord Howe, Norfolk, and Kermadec Islands, Southwest Pacific Ocean. Pacific Science. 47 (2). 136-170.

Froese, R. \& D. Pauly. (eds.). 2006. Fish base. World Wide Web electronic publication www. fishbase. org, version (06/2006).

Kailola, P.J. 1987. The fishes of Papua New Guinea: $A$ revised and annotated checklist. Vol.II Scorpaenidae to Callionymidae. Research Bulletin No.41. Research Section. Departement of Fisheries and Marine Resources. Papua New Guinea. p. 358.

Kuiter, R. H. \& T. Tonozuka. 2001. Pictorial guide to Indonesian reef fishes. Part 2. Fusiliers, Dragonets, Caesionidae, Callionymidae. Zoonetics, Australia. 304-622 p.445. fig. A-B

Lieske, E. \& R. Myers. 1994. Coral reef fishes. Collins Pocket Guide. Indo-Pacific and Caribbean including the Red Sea. Haper Collins Publishers. 400 p.

Masuda, H., K. Amaoka, C. Araga, T. Uyeno, \& T. Yoshino. 1984. The fishes of the Japanese Archipelago. Vol.1. Tokai University Press. Tokyo. Japan. 437 p. (text). 199. pl. 190-A.

Myers, R. F. 1991. Micronesian reef fishes. Second Ed. Coral Graphics. Barrigada. Guam. 298 p.

Mora, C., P. M. Chittaro, P. F. Sale, J. P. Kritzer, \& S. A. Ludsin. 2003. Patterns and processes in reef fish diversity. Nature. 421. 933-936.

Mundy, B. C. 2005. Checklist of the fishes of the Hawaiian Archipelago. Bishop Mus. Bulletin Zoology. (6). 1-704. 416 
Nelson, J. S. 1984. Fishes of the world. 2nd edition. John Wiley \& Sons. Book Fish. World. i-xv+1-523 $\mathrm{pp}$.

Phung, N. H., L. T. Phan, N. N. Thi, N. P. Dinh, D. T. N. Nhung, \& N. V. Luc. 1995. Checklist of marine fishes in Vietnam. Vol.3. Order Perciformes, Suborder Percoidei, and Suborder Echeneoidei. Sc. and Tech. Publish. House. Vietnam. P. 536.

Randall, J. E. 2001. Cirrhitidae In K. E. Carpenter and V. H. Niem (eds.). Fao Species Identification Guide for Fishery Purposes, the Living Marine Resources of the Western Central Pacific. Vol.5. Bony Fishes Part 3 (Menidae to Pomacentridae). Food and Agriculture Organization of the United Nations. Rome. 2001.

Randall, J. E., G. R. Allen, \& R. C. Steene. 1990. Fishes of the great barrier reef and coral reef. University of Hawaii Press. Honolulu. Hawaii. 989 pp.

Randall, J. E. \& C. Anderson. 1993. Annotated checklist of the epipelagic and shore fishes of the
Maldives Islands. Ichthyology Bulletin of the J. L. B. Smith Inst. of Ichthyology. 59. 47. 15.

Randall, J. E. \& K. K. P. Lim. (eds.). 2000. A checklist of the fishes of the South China Sea. Raffles Bulletin Zoology Supply. (8). 569-667.

Randall, J. E. 1963. Review of the hawkfishes (family Cirrhitidae). Procidding U. S. Natl. Mus. 114. 389451.

Randall, J. E. 1995. Coastal fishes of Oman. University of Hawaii Press. Honolulu. Hawaii. 439 p. 150 . fig. 359 .

Randall, J. E., H. Ida, K. Kato, R. L. Pyle, \& J. L. Earle. 1997. Annotated checklist of inshore fishes of the Ogasawara Islands. Nat. Sci. Mus. Monography. (11). 1-74.

Winterbottom, R. \& R. C. Anderson. 1997. A revised checklist of the epipelagic and shore fishes of the Chagos Archipelago. Central Indian Ocean. Ichthyology Bulletin Smith. Inst. (66). 1-28. 14. 
